\title{
Pengembangan perangkat pembelajaran geometri dengan mengadaptasi model CORE untuk meningkatkan efikasi diri
}

\section{Danis Agung Nugroho}

SMA Takhassus Al-Qur'an. Jalan KH. Asy'ariah No. 29, Kalibeber, Wonosobo, Jawa Tengah Indonesia Email: danisagung@gmail.com

* Corresponding Author

\begin{tabular}{ll} 
ARTICLE INFO & ABSTRACT \\
\hline $\begin{array}{l}\text { Article history } \\
\text { Received: } 7 \text { Nov. 2017; }\end{array}$ & $\begin{array}{l}\text { Penelitian ini bertujuan untuk menghasilkan perangkat pembelajaran yang } \\
\text { diadaptasi dari model CORE (Connecting, Organizing, Reflecting, dan }\end{array}$ \\
$\begin{array}{l}\text { Revised: } 27 \text { May 2019; } \\
\text { Accepted: } 29 \text { May 2019 }\end{array}$ & $\begin{array}{l}\text { siswa. Pengembangan perangkat menggunakan model pengembangan Borg dan } \\
\text { Gall yang dimodifikasi oleh peneliti dengan tahapan: (1) studi pendahuluan, (2) } \\
\text { perencanaan, (3) pengembangan rancangan produk awal, (4) uji coba terbatas, }\end{array}$ \\
$\begin{array}{l}\text { Keywords } \\
\text { pengembangan; perangkat } \\
\text { pembelajaran; geometri; } \\
\text { model pembelajaran CORE; } \\
\text { efikasi diri; development; } \\
\text { learning kits; geometry; } \\
\text { CORE instructional model; } \\
\text { produk akhir. Uji coba produk dilakukan di SMA Negeri 1 Prambanan Sleman } \\
\text { dengan melibatkan 52 siswa dan seorang guru matematika. Instrumen yang } \\
\text { digunakan terdiri atas lembar validasi, lembar observasi keterlaksanaan pem- } \\
\text { belajaran, lembar penilaian guru terhadap kepraktisan perangkat pembelajaran, } \\
\text { angket penilaian siswa terhadap kepraktisan LKS dan proses pembelajaran, dan } \\
\text { angket efikasi diri siswa dalam belajar geometri. Hasil penelitian adalah } \\
\text { perangkat pembelajaran yang terdiri dari RPP dan LKS dengan mengadaptasi }\end{array}$ \\
$\begin{array}{l}\text { model pembelajaran CORE yang memenuhi kriteria valid, praktis, dan efektif } \\
\text { untuk meningkatkan efikasi diri siswa. }\end{array}$
\end{tabular}

This research aimed to produce a valid, practical, and effective learning kits adapted from CORE (Connecting, Organizing, Reflecting, and Extending) model to improve student's self-efficacy. The development refered to the modified Borg and Gall model which consists of: (1) preliminary studies, (2) plan, (3) initial product design development, (4) limited trial, (5) revision phase I, (6) operational trials, (7) revision phase II, dan (8) final product dissemination. The product was implemented at SMA Negeri 1 Prambanan Sleman which involved 52 students and the mathematics teacher. The instruments used in this research were validation sheets, the observation sheet of learning implementation, an evaluation sheet for practicality of lesson plans and worksheets by the teacher, the questionnaire for practicality of worksheets and learning process, and student's self-efficacy in geometry learning questionnaire. The result was a valid, practical, and effective learning kits which consist of lesson plans and worksheets adapted from CORE instructional model to improve selfefficacy.

This is an open access article under the CC-BY-SA license.

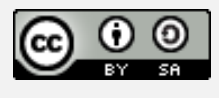

How to Cite: Nugroho, D. (2019). Pengembangan perangkat pembelajaran geometri dengan mengadaptasi model CORE untuk meningkatkan efikasi diri. Jurnal Riset Pendidikan Matematika, 6(1), $39-52$. doi:https://doi.org/10.21831/jrpm.v6i1.11599

\section{PENDAHULUAN}

Pembelajaran geometri merupakan bagian dari pembelajaran matematika yang memiliki peran penting bagi siswa untuk meningkatkan kompetensi siswa. Peran pembelajaran matematika sebagaimana dinyatakan dalam Peraturan Menteri Pendidikan dan Kebudayaan Republik Indonesia Nomor 59 
Tahun 2014 adalah sebagai sarana untuk membekali siswa dengan kemampuan berpikir logis, analitis, sistematis, kritis, inovatif, dan kreatif, serta kemampuan bekerjasama (Menteri Pendidikan dan Kebudayaan Republik Indonesia, 2014b). Sementara itu, berdasarkan pernyataan National Council of Teacher Mathematics (2000, p. 308), pembelajaran geometri pada siswa SMA bertujuan agar siswa dapat menganalisis karakteristik dan sifat-sifat dari bentuk geometri dua dan tiga dimensi serta mengembangkan argumen-argumen matematis tentang relasi-relasi geometris (geometric relationships), menetapkan suatu lokasi dan menjelaskan hubungan spasial menggunakan koordinat geometri dan sistem representatif lainnya, menerapkan transformasi dan menggunakan simetri untuk menganalisis situasi-situasi matematis, dan menggunakan visualisasi, penalaran spasial, dan pemodelan geometris untuk menyelesaikan permasalahan. Dalam hal ini, guru memiliki tanggung jawab yang besar dalam mempersiapkan kegiatan belajar siswa agar dapat mencapai tujuan pembelajaran geometri secara optimal.

Salah satu bentuk persiapan guru adalah mengembangkan perangkat pembelajaran. Idealnya, guru dapat mengembangkan perangkat pembelajaran secara mandiri. Akan tetapi, pengembangan perangkat pembelajaran berbasis Kurikulum 2013 masih dirasa sulit bagi guru, terlebih pengembangan tersebut dilakukan oleh guru secara mandiri. Hal ini didasarkan pada hasil wawancara dengan guru SMA Negeri 1 Prambanan Sleman bahwa guru masih merasa sulit dalam mengembangkan perangkat pembelajaran, khususnya RPP dan LKS yang sesuai dengan ketentuan dalam Kurikulum 2013. Kesulitan guru terletak pada bagian penjabaran indikator ketercapaian Kompetensi Dasar (KD), penyusunan langkah-langkah kegiatan pembelajaran yang memuat sintaks dari model pembelajaran yang digunakan dan pengaitannya dengan pendekatan saintifik, dan penyusunan penilaian yang mencakup keempat aspek Kompetensi Inti (KI). Selain itu, guru juga mengalami kesulitan dalam mengembangkan LKS yang dapat memfasilitasi kegiatan belajar siswa sesuai dengan RPP yang telah dikembangkannya.

Kesulitan guru di dalam mengembangkan perangkat pembelajaran tidak hanya berkaitan dengan prosedur atau teknis pengembangan, tetapi juga berkaitan dengan ruang lingkup materi yang dikembangkan. Pengembangan perangkat pembelajaran pada materi geometri dianggap lebih sulit dibanding pengembangan pada materi matematika lainnya. Materi geometri bagi siswa SMA memuat objek-objek geometri yang perlu diilustrasikan dalam bentuk gambar agar memudahkan siswa dalam mengamati dan mengidentifikasi objek tersebut. Di dalam proses tersebut, guru memerlukan waktu yang cukup lama, ketelitian yang tinggi, dan keterampilan yang memadai. Ketersediaan referensi pengembangan yang berkualitas dan sesuai dengan permasalahan tersebut sangat diperlukan oleh guru, agar guru dapat mendayagunakan waktu secara optimal dalam mengembangkan perangkat pembelajaran geometri.

Aspek lain di dalam pembelajaran geometri yang juga harus diperhatikan dalam mengembangkan perangkat pembelajaran adalah kebutuhan siswa. Berdasarkan hasil wawancara dengan guru, siswa membutuhkan pembelajaran yang dapat meningkatkan keyakinannya dalam belajar geometri. Pada pembelajaran geometri yang dilakukan selama ini, guru menilai bahwa masih banyak siswa yang kurang yakin terhadap kemampuannya sendiri dalam menyelesaikan tugas-tugas geometri. Siswa bahkan merasa tidak yakin dapat berhasil dalam belajar geometri. Hal ini diduga berpengaruh terhadap hasil belajar siswa pada materi geometri yang belum optimal. Permasalahan tersebut mengindikasikan terdapatnya masalah efikasi diri siswa dalam belajar geometri. Berdasarkan pendapat (Bandura, 1995, p. 2; Margolis \& Mccabe, 2006; Santrock, 2010, p. 473; Schunk, 1995; Wade \& Tavris, 2007) efikasi diri adalah keyakinan seseorang terhadap kemampuannya dalam mengatur dan melaksanakan suatu tugas, menguasai situasi, mencapai suatu tujuan, dan menguasai suatu keterampilan. Permasalahan tentang efikasi diri belum mendapat perhatian khusus dari pihak-pihak yang terkait langsung dalam pembelajaran, seperti guru dan siswa itu sendiri. Selama ini, guru dan siswa hanya terfokus pada bagaimana mencapai prestasi belajar yang tinggi dari pada memperhatikan aspek-aspek penting lainnya seperti efikasi diri. Sebagaimana dinyatakan oleh Ayda dan Widjajanti (2014, p. 217), efikasi diri siswa merupakan faktor penting untuk mencapai keberhasilan pembelajaran matematika.

Permasalahan efikasi diri siswa juga ditinjau dari analisis data hasil pengisian angket awal efikasi diri siswa dalam belajar geometri. Angket tersebut diisi oleh 25 siswa kelas X IIS 2 dan 21 siswa kelas XI MIA 4 SMA Negeri 1 Prambanan Sleman. Rata-rata skor efikasi diri siswa kelas X IIS 2 dan XI MIA 4 secara berturut-turut sebesar 86,56 dan 90,10 dimana keduanya termasuk pada kategori "sedang". Persentase banyaknya siswa yang memiliki efikasi diri dengan kategori "tinggi" hanya sebesar 8,00\% dari seluruh siswa kelas X IIS 2 dan 19,05\% dari seluruh siswa kelas XI MIA 4. Pada hasil ini juga 
ditunjukkan tidak adanya siswa yang memiliki efikasi diri dengan kategori "sangat tinggi". Berdasarkan hal tersebut, efikasi diri siswa dalam belajar geometri penting untuk ditingkatkan.

Berdasarkan uraian permasalahan tersebut, penting untuk dilakukan pengembangan perangkat pembelajaran geometri yang diorientasikan untuk meningkatkan efikasi diri siswa. Di dalam pengembangan tersebut, perlu diperhatikan pemilihan model pembelajaran yang relevan dengan permasalahan yang ingin diatasi. Model pembelajaran yang cocok untuk meningkatkan efikasi diri siswa adalah model pembelajaran yang berorientasi pada penguatan pengalaman belajar siswa. Hal ini didasarkan pada pendapat (Bandura, 1997, pp. 3-5; Brown, Malou, \& Schutte, 2013, pp. 16-19; Usher \& Pajares, 2009), bahwa penguatan pengalaman dapat berpengaruh positif terhadap efikasi diri. Di samping itu, Margolis dan Mccabe (2006, pp. 220-225) menyebutkan beberapa ciri dalam pembelajaran yang dapat meningkatkan efikasi diri siswa, diantaranya: (1) guru merencanakan tugas-tugas tantangan secara cukup, (2) guru menggunakan model-model tutor sebaya, (3) guru bersama dengan siswa menguatkan usaha dan mengoreksi strategi yang digunakan siswa, dan (4) guru bersama dengan siswa memberikan timbal balik yang sering, terfokus, dan spesifik.

Salah satu model pembelajaran yang sesuai dengan ciri-ciri tersebut adalah model pembelajaran CORE (Connecting, Organizing, Reflecting, dan Extending). R. G. Miller dan Calfee (2004, p. 21) menyatakan bahwa model pembelajaran CORE dapat diterapkan dalam pembelajaran yang berbasis pengalaman. Model ini terdiri dari empat tahapan pembelajaran, yaitu tahap Koneksi (Connecting), tahap Organisasi (Organizing), tahap Refleksi (Reflecting), dan tahap Ekstensi (Extending). Ciri-ciri penggunaan tutor sebaya untuk meningkatkan efikasi diri siswa berhubungan dengan kegiatan pada tahap Organisasi dalam model pembelajaran CORE yang melibatkan interaksi antarsiswa dengan metode diskusi. Sedangkan ciri-ciri adanya timbal balik antara guru dan siswa yang sering, terfokus, dan spesifik dapat ditemukan pada tahap Refleksi dalam model pembelajaran CORE. Sementara itu, ciri-ciri penguatan pengalaman dapat ditemukan pada tahap Ekstensi dalam model pembelajaran CORE. Berdasarkan kesesuaian hubungan tersebut, model pembelajaran CORE dipilih oleh peneliti pada pengembangan perangkat pembelajaran geometri yang diorientasikan untuk meningkatkan efikasi diri siswa.

Model pembelajaran merupakan bagian yang penting dan tidak dapat dipisahkan dari kegiatan belajar. Berdasarkan (Günter, Estes, \& Schwab, 1990, p. 67; Hosnan \& Sikumbang, 2014, p. 181; Menteri Pendidikan dan Kebudayaan Republik Indonesia, 2014a; Soekamto \& Winataputra, 1997; Trianto, 2010, p. 51), model pembelajaran adalah kerangka konseptual atau pola yang menggambarkan tahap-tahap yang sistematis dalam mengorganisasikan pengalaman belajar bagi para siswa untuk mencapai tujuan pembelajaran dan berfungsi sebagai pedoman bagi guru dan perancang pembelajaran dalam merencanakan dan melaksanakan pembelajaran di kelas maupun tutorial secara efektif. Model pembelajaran dipilih dan dikembangkan oleh guru dengan mempertimbangkan relevansinya pada tujuan yang akan dicapai. Tidak ada satu model pembelajaran yang sekaligus dapat memenuhi semua tujuan pembelajaran. Hal ini dikarenakan setiap model pembelajaran memiliki karakteristik yang berbeda antara satu dengan lainnya.

Berkaitan dengan hal tersebut, model pembelajaran CORE yang diterapkan oleh R. G. Miller dan Calfee (2004) merupakan salah satu yang paling relevan dan efektif untuk meningkatkan efikasi diri siswa. Hal ini didasarkan dari beberapa penelitian di antaranya penelitian yang dilakukan oleh Nurfayziah (2012) dan Deswita (2015). Curwen, Miller, White-smith, dan Calfee (2010, p. 133) menyatakan bahwa model pembelajaran CORE dapat diterapkan pada semua mata pelajaran. Karakteristik model pembelajaran CORE dapat dilihat dari sintaknya yang terdiri dari: (1) tahap koneksi, yaitu menghubungkan pengetahuan (connecting knowledge), (2) tahap organisasi, yaitu mengorganisasikan informasi (organizing information), (3) tahap refleksi, yaitu melakukanrefleksi dalam kegiatan belajar (reflecting on learning), dan (4) tahap ekstensi, yaitu memperluas pengalaman (extending the experience).

Tahap koneksi merupakan tahap yang memuat kegiatan belajar siswa dalam menghubungkan pengetahuan yang dimilikinya dengan informasi yang diterima atau dipelajarinya. Tahap ini menjadi tolak ukur keefektifan suatu pembelajaran. Hal ini didasarkan pada pendapat Dymock (2005, p. 178) bahwa suatu pembelajaran yang efektif adalah pembelajaran yang dapat menghubungkan siswa dengan topik pembelajarannya. Kegiatan belajar siswa yang dapat dilakukan pada tahap ini meliputi: (1) mengingat kembali (recall), membuat mata rantai (link) dan merangkai ide-ide (Bruning, Schraw, \& Ronning, 2010, p. 205), (2) mengingat kembali tanggal atau fakta atau daftar informasi tertentu dan 
sekumpulan instruksi (Caine \& Caine, 1997, p. 41), dan (3) mendengarkan, membaca, mencium, merasakan, dan menulis (Henson \& Eller, 2012, p. 249).

Tahap organisasi merupakan tahap di mana siswa mengoranisasikan berbagai informasi yang diperolehnya ke dalam suatu bentuk yang lebih sistematis agar lebih mudah dipahami. Kegiatan mengorganisasikan informasi sangat penting dalam mengonstruksi pengetahuan siswa (Bruning et al., 2010 , p. 205). Kegiatan belajar yang dapat dilakukan oleh siswa pada tahap ini di antaranya: (1) mengumpulkan fakta-fakta dan mengorganisasikan informasi-informasi baru (Bruning et al., 2010), dan (2) membuat peta konsep (Novak \& Cañas, 2008).

Tahap refleksi merupakan tahap yang memuat kegiatan siswa dalam melakukan refleksi atau perenungan terhadap kegiatan belajar yang telah dilakukannya. Kegiatan refleksi menurut Dymock (2005) memungkinkan siswa untuk menjelaskan atau mengkritik isi, struktur, dan strategi-strategi. Sedangkan menurut R. G. Miller dan Calfee (2004, p. 23), pada tahap Refleksi siswa diberi kesempatan oleh guru untuk memikirkan apa yang telah dipelajari dalam kelompok kecil maupun besar dengan cara mengoreksi dan memadatkan isi pengetahuan. Kegiatan belajar siswa pada tahap ini di antaranya: (1) menyajikan, mengatur, menjelaskan, dan mempertahankan ide (Bruning et al., 2010), dan (2) mengalami, menginterpretasikan pengalaman secara spontan, mengidentifikasi masalah atau pertanyaan yang didasarkan pada pengalaman, menghasilkan penjelasan yang mungkin untuk masalah atau pertanyaan yang diajukan, merumuskan hipotesis, dan bereksperimen atau menguji hipotesis yang dipilih (Rodgers, 2002, p. 851).

Tahap ekstensi merupakan tahap di mana siswa diberi kesempatan untuk memperluas pengalaman belajarnya dengan cara menggeneralisasi pengetahuan yang diperoleh siswa selama proses belajar (Suyatno, 2009, p. 67). Kegiatan belajar yang dapat dilakukan siswa pada tahap ini meliputi: (1) membahas topik-topik baru lainnya yang relevan (Dymock, 2005, p. 2), dan (2) mencari jawaban dari pertanyaan yang mereka ajukan sendiri (Bruning et al., 2010).

Di dalam pembelajaran berbasis Kurikulum 2013, model pembelajaran CORE diadaptasi oleh guru dengan cara disintesiskan dengan sintak pendekatan saintifik. Berdasarkan Permendikbud Nomor 103 Tahun 2014, pembelajaran dengan pendekatan saintifik memuat sintak yang terdiri dari aktivitas mengamati, menanya, mengumpulkan informasi/melakukan eksperimen, menalar, dan mengomunikasikan. Berdasarkan sintesis tersebut diperoleh sintak model pembelajaran CORE dengan pendekatan saintifik yang meliputi: (1) tahap koneksi dengan aktivitas mengamati dan menanya, (2) tahap organisasi dengan aktivitas mengasosiasikan informasi/ eksperimen, (3) tahap refleksi dengan aktivitas menalar dan mengomunikasikan dan (4) tahap ekstensi dengan aktivitas menyelesaikan masalah geometri. Sintesis tersebut dilakukan dengan cara mengombinasikan kegiatan belajar siswa dengan pendekatan saintifik dan kegiatan belajar siswa dengan model pembelajaran CORE yang saling berhubungan.

Pembelajaran tidak dilaksanakan melainkan didasarkan pada suatu tujuan. Adapun tujuan dilaksanakannya pembelajaran adalah untuk meningkatkan kompetensi siswa. Terdapat banyak kompetensi dari diri siswa yang perlu ditingkatkan, salah satunya efikasi diri (Zimmerman, Bonner, \& Kovach, 1996, p.27). Efikasi diri adalah keyakinan seseorang terhadap kemampuannya dalam mengatur dan melaksanakan suatu tugas, menguasai situasi, mencapai suatu tujuan, dan menguasai suatu keterampilan (Bandura, 1995, p. 2; Margolis \& Mccabe, 2006; Santrock, 2010, p. 473; Schunk, 1995; Wade \& Tavris, 2007). Zimmerman (2000) menyatakan bahwa efikasi diri siswa sangat penting untuk diperhatikan oleh guru dan siswa karena efikasi diri tersebut berkaitan dengan keyakinan siswa terhadap keefektifan cara belajar yang digunakan. Bruning et al. (2010) berpendapat bahwa efikasi diri merupakan faktor yang sangat mempengaruhi motivasi siswa dalam melaksanakan suatu tugas dan menghadapi tantangan-tantangan yang ada. Berdasarkan hal tersebut, pengukuran terhadap efikasi diri siswa menjadi salah satu hal yang penting untuk dilakukan agar guru dapat mengetahui efikasi diri siswa sehingga guru dapat merancang pembelajaran yang efektif dan sesuai dengan kondisi serta kebutuhan belajar siswanya.

Pengukuran efikasi diri siswa pada penelitian ini dilakukan dengan metode angket. Skala yang digunakan pada pengukuran efikasi diri merujuk pada pendapat Bandura (2006, p. 312) yang telah dimodifikasi dari skala diskret 10-an dengan interval 0 sampai dengan 100 menjadi skala diskret 10-an dengan interval 0 sampai dengan 10. Berdasarkan pendapat Bandura (2006, p. 312), skala efikasi bersifat unipolar, yakni terbentang dari 0 sampai pada suatu nilai maksimum tertentu. Skala tersebut tidak melibatkan bilangan negatif karena tidak ada kriteria yang lebih rendah dari kriteria "tidak dapat melakukan" yang direpresentasikan dengan bilangan 0. Penggunaan teknik skala diskret 10-an pada 
angket efikasi diri siswa memberikan peluang opsi yang lebih banyak bagi siswa dalam memilih derajat efikasi diri berdasarkan perasaan dan keyakinannya sendiri.

Angket efikasi diri siswa berisi sejumlah pernyataan yang dirumuskan dari indikator-indikator efikasi diri. Penjabaran indikator tersebut didasarkan pada aspek-aspek yang termuat dalam definisi konseptual efikasi diri. Berdasarkan rumusan definisi konseptual, efikasi diri memuat tiga aspek, yaitu: (1) keyakinan dalam pengaturan tugas, (2) keyakinan dalam penguasaan situasi, dan (3) keyakinan dalam pencapaian hasil. Indikator-indikator dari keyakinan dalam pengaturan tugas terdiri dari mampu merencanakan tugas dan mampu melaksanakan tugas. Indikator-indikator dari keyakinan dalam penguasaan situasi terdiri dari mampu menyesuaikan diri dan mampu mengatasi hambatan. Sedangkan indikator-indikator dari keyakinan dalam pencapaian hasil terdiri dari mampu menguasai suatu keterampilan dan mampu mencapai tujuan. Keenam indikator tersebut digunakan untuk merumuskan pernyataan-pernyataan dalam angket efikasi diri siswa yang digunakan pada penelitian ini.

Berkaitan dengan pembelajaran geometri, efikasi diri yang diukur meliputi keyakinan dalam merencanakan, melaksanakan, menyesuaikan diri, mengatasi hambatan, menguasai keterampilan, dan mencapai tujuan belajar. Keyakinan dalam merencanakan meliputi keyakinan dalam apersepsi dan menyiapkan peralatan dan materi/referensi geometri yang akan dipelajari. Keyakinan dalam melaksanakan meliputi keyakinan dalam mengikuti pelajaran, mengerjakan tugas, dan menggunakan alat/media geometri. Keyakinan dalam menyesuaikan diri meliputi keyakinan dalam menggunakan berbagai sumber belajar dan belajar geometri secara mandiri atau berkelompok. Keyakinan dalam mengatasi hambatan meliputi keyakinan dalam mengidentifikasi kesulitan belajar geometri dan cara mengatasinya. Keyakinan dalam menguasai keterampilan meliputi keyakinan dalam menerapkan pengetahuan geometrinya dalam menyelesaikan masalah dan menghasilkan suatu karya. Keyakinan dalam mencapai tujuan belajar meliputi keyakinan dalam menggambarkan bangun-bangun geometri dengan benar dan terampil, membayangkan, dan menguasai materi geometri.

Cara untuk meningkatkan efikasi diri siswa dalam pembelajaran merujuk pada beberapa pendapat sebagai berikut. Margolis dan Mccabe (2006) menyatakan bahwa efikasi diri siswa dapat ditingkatkan dengan strategi-strategi yang dilakukan melalui tindakan maupun ucapan. Strategi untuk meningkatkan efikasi diri siswa melalui tindakan meliputi: (1) merencanakan tugas-tugas tantangan secara secara cukup (plan moderately challenging tasks), (2) menggunakan model-model tutor sebaya (use peer models), (3) membelajarkan strategi pembelajaran secara spesifik (teach specific learning strategies), (4) mendapatkan keuntungan dari pilihan dan minat siswa (capitalize on student choice and iterest), dan (5) menguatkan usaha dan mengoreksi strategi yang digunakan siswa (reinforce efforts and correct strategy use). Sedangkan strategi yang digunakan untuk meningkat efikasi diri siswa melalui ucapan meliputi: (1) membujuk siswa untuk berusaha (encourage students to try), (2) menekankan keberhasilan-keberhasilan yang baru saja dicapai (stress recent successes), (3) memberikan timbal balik yang sering, terfokus, dan spesifik (give frequent, focused, task-spesific feedback), dan (4) menekankan pernyataan-pernyataan dukungan yang berguna (stress functional attribution statements). Di samping itu, menurut Gillies (2007, p. 5), pembelajaran yang melibatkan siswa untuk berkontribusi dan menerima pengakuan atas usaha mereka dalam suatu kelompok belajar dapat meningkatkan efikasi diri siswa tersebut.

Berdasarkan latar belakang masalah berikut kajian teori yang telah dimukakan sebelumnya, pengembangan perangkat pembelajaran geometri dengan mengadaptasi model CORE perlu dilakukan, agar efikasi diri siswa dapat ditingkatkan. Dengan demikian penelitian dan pengembangan ini bertujuan untuk menghasilkan perangkat pembelajaran geometri dengan mengadaptasi model CORE untuk meningkatkan efikasi diri siswa yang berkualitas.

\section{METODE}

Penelitian ini menggunakan pendekatan kualitatif dan kuantitatif dengan desain penelitian dan pengembangan. Produk penelitian adalah perangkat pembelajaran yang diadaptasi dari model CORE (Connecting, Organizing, Reflecting, dan Extending) yang berkualitas baik untuk meningkatkan efikasi diri siswa. Kualitas tersebut didasarkan pada kriteria penilaian kualitas produk menurut Nieveen (1999, p. 127) yang meliputi kevalidan, kepraktisan, dan keefektifan. Model pengembangan produk yang digunakan pada penelitian ini merujuk pada model pengembangan (Borg \& Gall, 1983, p. 775) yang dimodifikasi oleh peneliti dengan tahapan: (1) studi pendahuluan, (2) perencanaan, (3) pengembangan 
rancangan produk awal, (4) percobaan terbatas, (5) revisi tahap I, (6) percobaan operasional, (7) revisi tahap II, dan (8) pembagian produk akhir.

Penelitian ini dilaksanakan selama enam bulan pada bulan Maret sampai dengan Agustus tahun 2016 dengan rincian sebagai berikut: (1) studi pendahuluan dan perencanan dilakukan pada bulan Maret dan minggu pertama bulan April, (2) pengembangan rancangan produk awal dilakukan pada minggu ke5 bulan Maret sampai minggu ke-4 bulan April, (3) percobaan terbatas dilakukan pada minggu ke-4 bulan April, (4) revisi I dilakukan pada bulan April, (5) percobaan operasional dilakukan pada minggu ke-4 bulan April sampai minggu ke-3 bulan Mei, (6) revisi II dilakukan pada minggu ke-4 bulan Mei sampai minggu ke-3 bulan Agustus, dan (7) diseminasi produk akhir dilakukan pada minggu ke-3 dan ke-4 bulan Agustus. Tempat studi pendahuluan, percobaan terbatas, dan percobaan operasional dilakukan di SMA Negeri 1 Prambanan Sleman.

Subjek percobaan meliputi 52 siswa dan seorang guru matematika SMA Negeri 1 Prambanan Sleman. Subjek percobaan terbatas adalah 6 siswa kelas XI MIA 2 dan guru yang mengajar matematika pada kelas tersebut. Sedangkan subjek percobaan operasional adalah 25 siswa kelas X IIS 2 (mendapat pembelajaran materi jarak dan sudut) dan 21 siswa kelas XI MIA 4 (mendapat pembelajaran materi transformasi geometri) serta guru yang mengajar matematika pada kelas tersebut. Subjek dipilih berdasarkan hasil prapenelitian di SMA Negeri 1 Prambanan Sleman dengan cara berkonsultasi dengan wakil kepala sekolah bidang kurikulum sekolah.

Pengembangan produk diawali dengan kegiatan studi pendahuluan yang bertujuan untuk memperoleh informasi yang diperlukan dalam pengembangan perangkat pembelajaran dengan mengadaptasi model CORE untuk meningkatkan efikasi diri siswa. Pada tahap ini, dilakukan analisis kebutuhan guru dan siswa dalam pembelajaran geometri di SMA Negeri 1 Prambanan Sleman dan studi literatur tentang pengembangan perangkat pembelajaran berbasis Kurikulum 2013, materi geometri SMA, model pembelajaran CORE, dan efikasi diri. Tahap selanjutnya adalah tahap perencanaan yang dilakukan dengan cara mengumpulkan alat dan bahan yang diperlukan untuk mengembangkan perangkat pembelajaran berdasarkan hasil studi pendahuluan. Pada tahap ini, juga dilakukan penyusunan jadwal penelitian agar tahap-tahap pengembangan dapat terlaksana dengan sistematis dan tepat waktu. Tahap pengembangan rancangan produk awal dilakukan untuk menentukan, menyusun, dan menuliskan rancangan produk awal yang disebut draf RPP dan draf LKS. Kegiatan pada tahap tersebut meliputi penentuan Kompetensi Dasar (KD) dengan merujuk Peraturan Menteri Pendidikan dan Kebudayaan Republik Indonesia Nomor 69 Tahun 2013, penentuan indikator keberhasilan, penentuan materi dengan merujuk Peraturan Menteri Pendidikan dan Kebudayaan Republik Indonesia Nomor 64 Tahun 2013 dan Peraturan Menteri Pendidikan dan Kebudayaan Republik Indonesia Nomor 59 Tahun 2014, perancangan draf RPP dan LKS, dan validasi rancangan (Menteri Pendidikan dan Kebudayaan Republik Indonesia, 2013a, 2013b, 2014b).

Langkah-langkah operasional perancangan draf RPP, yaitu: (1) menuliskan judul, yaitu "Rencana Pelaksanaan Pembelajaran", (2) menuliskan identitas RPP yang meliputi satuan pendidikan, mata pelajaran, kelas/semester, materi pokok, alokasi waktu, submateri, dan "pertemuan ke-", (3) menuliskan Kompetensi Inti yang dikembangkan, meliputi uraian dari KI-1, KI-2, KI-3, dan KI-4, (4) menuliskan Kompetensi Dasar (KD) dan penjabaran indikator-indikator pencapaian dari masing-masing KD, (5) menuliskan tujuan pembelajaran yang sesuai dengan penjabaran indikator dari masing-masing KD, (6) menuliskan materi pembelajaran yang dirujuk dari silabus, buku teks, buku pegangan guru, dan sumber lainnya, (7) menuliskan model pembelajaran yang digunakan, yaitu CORE (Connecting, Organizing, Reflecting, dan Extending), dan metode pembelajaran, yaitu metode diskusi dan dapat ditambah dengan metode lainnya, (8) menuliskan langkah-langkah pembelajaran yang diuraikan secara spesifik pada kegiatan pendahuluan, kegiatan inti, dan kegiatan penutup yang dilengkapi dengan alokasi waktu pada setiap tahap pembelajaran. Kegiatan inti diuraikan berdasarkan tahap model pembelajaran CORE yang memuat aktivitas-aktivitas belajar menggunakan pendekatan saintifik, yaitu: (a) tahap connecting dengan aktivitas mengamati (observing) dan menanya (questioning), (b) tahap organizing dengan aktivitas mengasosiasikan informasi/eksperimen (experimenting), (c) tahap reflecting dengan aktivitas menalar (associating) dan mengomunikasikan (communicating), dan (d) tahap extending dengan aktivitas menyelesaikan masalah geometri, (9) menuliskan penilaian yang diuraikan berdasarkan jenis/teknik penilaian, instrumen penilaian, pedoman penskoran, dan penilaian akhir, dan (10) menuliskan media dan sumber pembelajaran. 
Sedangkan langkah-langkah operasional perancangan draf LKS, yaitu: (1) menuliskan kode LKS dan identitas siswa yang meliputi nama, sekolah, dan kelas, (2) menuliskan judul, yaitu "Lembar Kerja Siswa", (3) menuliskan identitas LKS yang terdiri dari mata pelajaran, kelas/semester, materi, submateri beserta keterangan "pertemuan ke-“, dan alokasi waktu, (4) menuliskan uraian KD yang ingin dicapai, (5) menuliskan petunjuk pengerjaan LKS, (6) menuliskan tahap koneksi dengan uraian kegiatan belajar yang dapat menghubungkan materi prasyarat yang telah dipelajari sebelumnya dengan materi yang akan dipelajari siswa dengan menyajikan gambar dan/atau pertanyaan yang membantu siswa mengingat materi prasyarat, (7) menuliskan tahap organisasi dengan uraian topik atau masalah yang dapat didiskusikan siswa secara berkelompok dengan menyajikan gambar, tabel, dan/atau pertanyaanpertanyaan, (8) menuliskan tahap refleksi dengan perintah untuk mengajukan suatu soal terkait materi yang dipelajaribeserta cara penyelesaiannya atau menjawab pertanyaan-pertanyaan untuk mengecek pemahaman siswa terhadap materi, (9) menuliskan tahap ekstensi dengan soal-soal berbasis masalah yang berkaitan dengan materi yang telah dipelajari pada pertemuan ini atau yang akan dipelajari pada pertemuan selanjutnya, dan (10) menuliskan tabel penilaian terdiri dari kolom nilai tahap koneksi, organisasi, refleksi, dan ekstensi serta kolom nilai rata-rata, dan kolom paraf guru.

Rancangan perangkat yang telah divalidasi selanjutnya diujicobakan secara terbatas dalam pembelajaran geometri pada siswa kelas XI MIA 2. Tahap ini bertujuan untuk mengetahui kepraktisan perangkat dan keterlaksanaan pembelajaran. Di samping itu, dilakukan penilaian guru terhadap kepraktisan perangkat dan penilaian siswa terhadap LKS dan proses pembelajaran. Hasil kegiatan tersebut digunakan untuk revisi tahap I. Tahap ujicoba operasional dilakukan pada 25 siswa kelas X IIS 2 dan 21 siswa kelas XI MIA 4 setelah dilakukannya revisi tahap I. Hasil dari tahap percobaan operasional kemudian dijadikan sebagai bahan untuk merevisi RPP dan LKS pada tahap revisi II yang menghasilkan produk akhir yang valid, praktis, dan efektif. Produk akhir dibagikan kepada guru matematika SMA Negeri 1 Prambanan Sleman dan dipublikasikan secara lebih luas di internet.

Data yang dikumpulkan berupa data kuantitatif dan data kualitatif. Data kualitatif yang diperoleh berupa saran dari validator dan guru dan masukan dari siswa. Sedangkan data kuantitatif yang diperoleh berupa skor-skor: (1) hasil penilaian validator terhadap validitas produk, (2) hasil penilaian guru terhadap kepraktisan perangkat pembelajaran, (3) hasil penilaian siswa terhadap kepraktisan LKS dan proses pembelajaran, dan (4) hasil angket efikasi diri siswa dalam belajar geometri.

Instrumen yang digunakan terdiri dari: (1) lembar validasi, (2) lembar observasi keterlaksanaan pembelajaran, (3) lembar penilaian guru terhadap kepraktisan perangkat pembelajaran, (4) angket penilaian siswa terhadap kepraktisan LKS dan proses pembelajaran, dan (5) angket efikasi diri siswa (AEDS) dalam belajar geometri. Instrumen AEDS yang digunakan terbukti valid berdasarkan hasil validasi ahli dengan skor kevalidan sebesar 33,5 yang termasuk pada kategori "sangat valid" dan reliabel dengan nilai estimasi reliabilitas sebesar 0,928 . Suatu instrumen dinyatakan reliabel jika estimasi reliabilitasnya lebih besar dari 0,60 (M. D. Miller, Linn, Gronlund, \& Linn, 2008, p. 132).

Analisis data dilakukan untuk mendapatkan bukti kevalidan, kepraktisan, dan keefektifan dari produk yang dikembangkan. Kategori kualitas produk tersebut merujuk pada kriteria penilaian kualitas produk menurut Azwar (2004, p. 163), seperti disajikan pada Tabel 1.

Tabel 1. Kriteria Penilaian Kualitas Produk

\begin{tabular}{cl}
\hline \multicolumn{1}{c}{ Interval Skor } & Kategori \\
\hline $\boldsymbol{X}>(\boldsymbol{M}+\mathbf{1}, \mathbf{5 0 s})$ & Sangat Baik \\
$(\boldsymbol{M}+\mathbf{0}, \mathbf{5 0 s})<\boldsymbol{X} \leq(\boldsymbol{M}+\mathbf{1}, \mathbf{5 0 s})$ & Baik \\
$(\boldsymbol{M}-\mathbf{0}, \mathbf{5 0 s})<\boldsymbol{X} \leq(\boldsymbol{M}+\mathbf{0}, \mathbf{5 0 s})$ & Cukup Baik \\
$(\boldsymbol{M}-\mathbf{1}, \mathbf{5 0 s})<\boldsymbol{X} \leq(\boldsymbol{M}-\mathbf{0}, \mathbf{5 0 s})$ & Tidak Baik \\
$\boldsymbol{X} \leq(\boldsymbol{M}-\mathbf{1}, \mathbf{5 0 s})$ & Sangat Tidak Baik \\
\hline
\end{tabular}

Berdasarkan pada Tabel 1 dijelaskan bahwa $X$ adalah skor aktual, $M$ adalah rata-rata skor ideal, dan $s$ adalah simpangan baku ideal. Sedangkan untuk menghitung nilai $M \frac{\text { skor maksimum+skor minimum }}{2}$, dan untuk menghitung $s=\frac{\text { skor maksimum-skor minimum }}{6}$.

Analisis data kevalidan produk dilakukan dengan menghitung rata-rata total skor kevalidan hasil penilaian validasi oleh ahli. Rata-rata total skor tersebut kemudian dikonversi menjadi data kualitatif untuk mengetahui tingkat kevalidan produk dengan mengacu pada Tabel 1. Adapun kategori kevalidan 
produk dapat dilihat pada Tabel 2. Produk dinyatakan valid apabila hasil penilaian validator minimal pada kategori "baik". Produk yang belum valid direvisi sesuai saran validator.

Analisis data kepraktisan produk meliputi analisis hasil: (1) observasi keterlaksanaan pembelajaran, (2) penilaian guru terhadap kepraktisan perangkat pembelajaran, dan (3) penilaian siswa terhadap LKS dan proses pembelajaran. Analisis kepraktisan dilakukan dengan menghitung persentase keterlaksanaan pembelajaran dan rata-rata skor kepraktisan hasil penilaian guru dan siswa. Produk dinyatakan praktis apabila skor kepraktisan minimal pada kategori "baik" dan rata-rata persentase keterlaksanaan pembelajaran minimal $80 \%$.

Kategori kepraktisan produk dilihat pada Tabel 3. Sedangkan rumus untuk mengetahui persentase keterlaksanaan pembelajaran dapat dilihat pada Persaman Rumus 1. Berdasarkan Persamaan Rumus 1 diketahui bahwa $P$ merupakan persentase keterlaksanaan pembelajaran, $M$ adalah kegiatan (item) yang terlaksana, dan $T$ adalah total item kegiatan pembelajaran.

$P=\frac{M}{T} \times 100 \%$

Analisis data keefektifan produk dilakukan dengan menghitung rata-rata skor efikasi diri siswa dalam belajar geometri dan persentase banyaknya siswa dengan efikasi diri minimal pada kategori "tinggi".

Tabel 2. Kategori Kevalidan Produk

\begin{tabular}{llccccc}
\hline \multirow{2}{*}{ No. } & Aspek & \multicolumn{5}{c}{ Kategori Kevalidan } \\
\cline { 3 - 7 } & Penilaian & Sangat Baik & Baik & Cukup Baik & Tidak Baik & Sangat Tidak Baik \\
\hline 1. & RPP & $X>160$ & $133,33<X \leq 160$ & $106,67<X \leq 133,33$ & $80<X \leq 106,67$ & $X \leq 80$ \\
2. & LKS & $X>76$ & $63,33<X \leq 76$ & $50,67<X \leq 63,33$ & $38<X \leq 50,67$ & $X \leq 38$ \\
\hline
\end{tabular}

Tabel 3. Kategori Kepraktisan Produk

\begin{tabular}{|c|c|c|c|c|c|c|}
\hline \multirow{2}{*}{ No. } & \multirow{2}{*}{ Penilaian } & \multicolumn{5}{|c|}{ Kategori Kepraktisan } \\
\hline & & Sangat Baik & Baik & Cukup Baik & Kurang Baik & Sangat Tidak Baik \\
\hline 1. & $\begin{array}{l}\text { Penilaian Guru: } \\
\text { a. RPP } \\
\text { b. LKS }\end{array}$ & $\begin{array}{l}X>40 \\
X>24\end{array}$ & $\begin{array}{c}33,33<X \leq 40 \\
20<X \leq 24\end{array}$ & $\begin{array}{c}26,67<X \leq 33,33 \\
16<X \leq 20\end{array}$ & $\begin{array}{c}20<X \leq 26,67 \\
12<X \leq 16\end{array}$ & $\begin{array}{l}X \leq 20 \\
X \leq 12\end{array}$ \\
\hline 2. & $\begin{array}{l}\text { Penilaian Siswa: } \\
\text { a. LKS } \\
\text { b. Proses } \\
\quad \text { Pembelajaran }\end{array}$ & $\begin{array}{l}X>32 \\
X>20\end{array}$ & $\begin{array}{l}26,67<X \leq 32 \\
16,67<X \leq 20\end{array}$ & $\begin{array}{l}21,33<X \leq 26,67 \\
13,33<X \leq 16,67\end{array}$ & $\begin{array}{l}16<X \leq 21,33 \\
10<X \leq 13,33\end{array}$ & $\begin{array}{l}X \leq 16 \\
X \leq 10\end{array}$ \\
\hline
\end{tabular}

Tabel 4. Kategori Efikasi Diri

\begin{tabular}{cl}
\hline Interval Rata-Rata Skor Efikasi Diri Siswa & \multicolumn{1}{c}{ Kategori } \\
\hline $135<X \leq 180$ & Sangat Tinggi \\
$105<X \leq 135$ & Tinggi \\
$75<X \leq 105$ & Sedang \\
$45<X \leq 75$ & Rendah \\
$0 \leq X \leq 45$ & Sangat Rendah \\
\hline
\end{tabular}

Produk dinyatakan efektif apabila efikasi diri siswa minimal pada kategori "tinggi" dan persentase banyaknya siswa dengan kriteria tersebut minimal $80 \%$. Kriteria keefektifan minimal dengan persentase $80 \%$ tersebut merujuk pada pendapat Morrison, Ross, Kemp, dan Kalman (2010, p. 289). Kategori efikasi diri siswa dilihat pada Tabel 4. Sementara itu, persentase banyaknya siswa dengan efikasi diri minimal pada kategori "tinggi" dihitung dengan Persamaan Rumus 2. Berdasarkan Persamaan Rumus $2 P$ adalah persentase banyaknya siswa dengan efikasi diri minimal pada kategori "tinggi"; $T$ adalah banyak siswa dengan efikasi diri "tinggi"; STadalah banyak siswa dengan efikasi diri "sangat tinggi"; dan $N$ adalah banyak keseluruhan responden.

$P=\frac{T+S T}{N} \times 100 \%$

\section{HASIL DAN PEMBAHASAN}

Hasil penelitian ini adalah perangkat pembelajaran geometri yang berkualitas yang terdiri dari RPP dan LKS yang diadaptasi dari model pembelajaran CORE untuk meningkatkan efikasi diri siswa 
dalam belajar geometri. Perangkat tersebut dikembangkan sesuai dengan prinsip-prinsip pengembangan perangkat pembelajaran berbasis Kurikulum 2013 yang menggunakan pendekatan saintifik dan diadaptasi dari model pembelajaran CORE. Kompetensi Dasar yang dikembangkan meliputi KD pada ruang lingkup geometri SMA kelas X, XI, dan XII. Berdasarkan materi pembelajarannya, perangkat tersebut dibagi menjadi tiga jenis, yaitu: (1) RPP dan LKS dengan materi jarak dan sudut (kelas X), (2) RPP dan LKS dengan materi transformasi geometri (kelas XI), dan (3) RPP dan LKS dengan materi diagonal bidang, diagonal ruang, dan bidang diagonal (kelas XII). Adapun karakteristik yang dimiliki perangkat tersebut di antaranya: (1) memuat langkah-langkah pembelajaran yang diadaptasi dari model CORE dengan pendekatan saintifik, yaitu tahap connecting dengan aktivitas mengamati (observing) dan menanya (questioning), tahap organizing dengan aktivitas mengasosiasikan informasi/eksperimen (experimenting), tahap reflecting dengan aktivitas menalar (associating) dan mengomunikasikan (communicating), dan tahap extending dengan aktivitas menyelesaikan masalah geometri, (2) memuat tujuan dan kegiatan pembelajaran geometri yang diarahkan pada peningkatan efikasi diri siswa, (3) memuat kegiatan pembelajaran yang dirancang untuk memfasilitasi siswa dalam mengonstruksi pengetahuan secara aktif dan memaksimalkan peran guru sebagai fasilitator, dan (4) memuat soal-soal berbasis masalah yang sesuai dengan indikator pencapaian KD. Soal-soal berbasis masalahyang dimuat pada perangkat ini merupakan variasi dan tantangan belajar bagi siswa yang diarahkan untuk memperluas pengalaman belajar siswa agar efikasi dirinya dapat meningkat.

Kualitas perangkat pembelajaran tersebut dianalisis dari tiga aspek, yaitu kevalidan, kepraktisan, dan keefektifannnya. Berdasarkan hasil penilaian ahli terhadap validitas produk diperoleh rata-rata skor dan kategori kevalidan produk yang ditunjukkan pada Tabel 5

Tabel 5. Kevalidan Produk

\begin{tabular}{ccc}
\hline Aspek Penilaian & Rata-Rata Skor & Kategori \\
\hline RPP & 113,6 & Sangat Baik \\
LKS & 76 & Baik \\
\hline
\end{tabular}

Pada Tabel 5 ditunjukkan bahwa RPP memenuhi kriteria valid dengan kategori "sangat baik". Sedangkan LKS memenuhi kriteria valid dengan kategori "baik". Sementara itu, hasil penilaian guru dan siswa terhadap kepraktisan produk ditunjukkan pada Tabel 6.

Tabel 6. Kepraktisan Produk Berdasarkan Penilaian Guru dan Siswa

\begin{tabular}{lcc}
\hline \multicolumn{1}{c}{ Penilaian } & Rata-Rata Skor & Kategori \\
\hline 1. Penilaian dari Guru: & & \\
a. RPP & 47 & Sangat Baik \\
b. LKS & 26 & Sangat Baik \\
2. Penilaian Siswa: & & \\
a. LKS & 30 & Baik \\
1) X IIS 2 & 31,33 & Baik \\
2) XI MIA 4 & 21 & Sangat Baik \\
b. Proses Pembelajaran & 20 & Baik \\
1) X IIS 2 & & \\
2) XI MIA 4 &
\end{tabular}

Berdasarkan Tabel 6, RPP dan LKS termasuk praktis dengan kategori "sangat baik" menurut penilaian guru dengan skor kepraktisannya secara berturut-turut sebesar 47 dan 26. Sedangkan menurut penilaian siswa kelas X IIS 2, LKS dan proses pembelajaran termasuk praktis dengan kategori secara berturut-turut "baik" dan "sangat baik". Adapun menurut penilaian siswa kelas XI MIA 4, LKS dan proses pembelajaran termasuk praktis dengan kategori "baik".

Selain itu, kepraktisan produk ditinjau juga dari hasil observasi keterlaksanaan pembelajaran menggunakan produk tersebut. Persentase keterlaksanaan kegiatan guru dan siswa kelas X IIS 2 secara berturut-turut sebesar $94,67 \%$ dan $94 \%$. Sedangkan persentase keterlaksanaan kegiatan guru dan siswa kelas XI MIA 4 secara berturut-turut sebesar 97\% dan 95\%. Berdasarkan data tersebut, keterlaksanaan pembelajaran pada siswa kelas X IIS 2 dan XI MIA 4 tergolong praktis dengan rata-rata persentase keterlaksanaan secara berturut-turut sebesar $94,3 \%$ dan $96 \%$.

Gambar 1 menunjukkan grafik keterlaksanaan pembelajaran dengan menggunakan perangkat pembelajaran geometri yang diadaptasi dari model CORE untuk meningkatkan efikasi diri siswa. 
Jurnal Riset Pendidikan Matematika, 6 (1), 2019 - 48

Danis Agung Nugroho

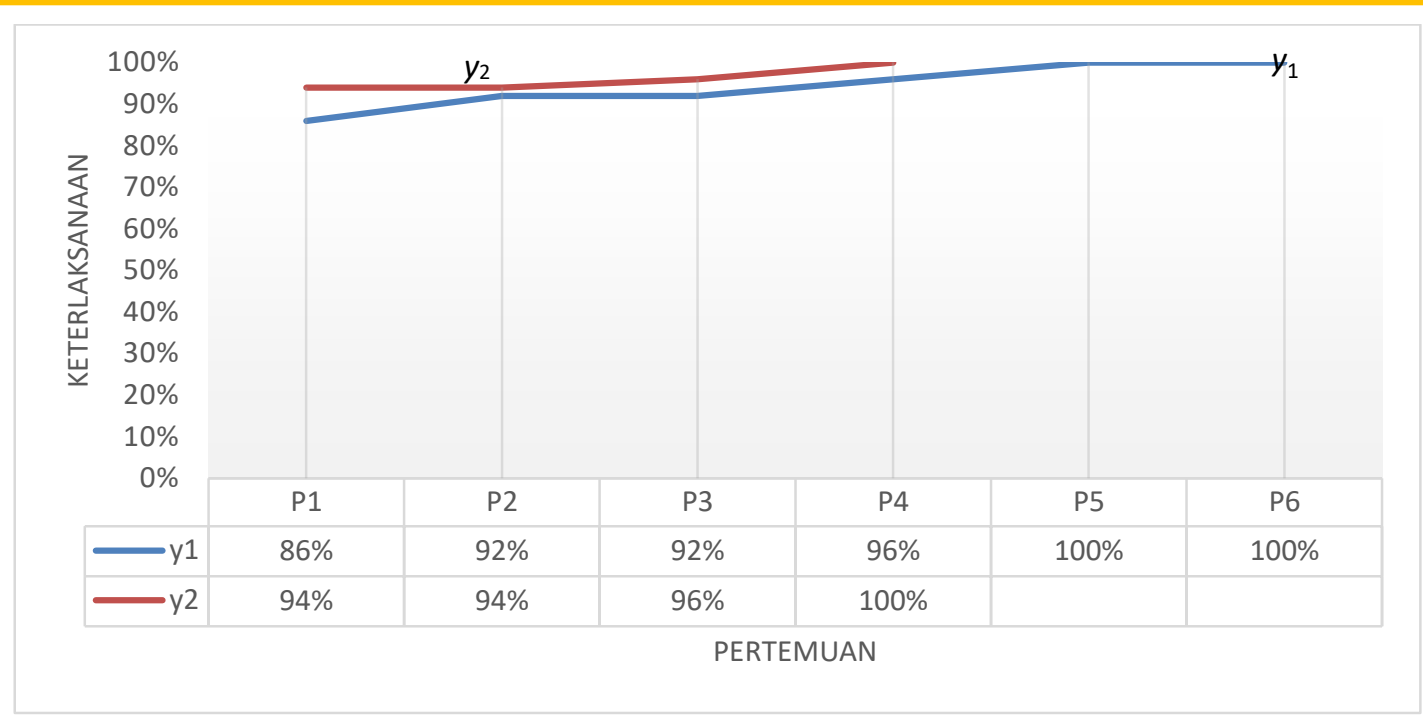

Gambar 1. Grafik Keterlaksanaan Pembelajaran dengan Mengimplementasikan Produk

Sebagaimana ditunjukkan pada Gambar 1, pembelajaran pada siswa kelas X IIS 2 dilaksanakan dalam 6 kali pertemuan (diilustrasikan dengan garis $y_{1}$ ). Sedangkan pembelajaran pada siswa kelas XI MIA 4 dilaksanakan dalam 4 kali pertemuan (diilustrasikan dengan garis $y_{2}$ ). Label P1 sampai dengan P6 pada Gambar 1 menunjukkan pertemuan pembelajaran.

Di dalam pelaksanaan pembelajaran menggunakan perangkat pembelajaran geometri yang diadaptasi dari model CORE untuk meningkatkan efikasi diri siswa, terdapat beberapa kegiatan guru dan siswa yang belum dapat terlaksana pada beberapa pertemuan pembelajaran di kelas X IIS 2 dan X MIA 4. Hal ini diindikasikan dari: (1) persentase keterlaksanaan pembelajaran pada pertemuan pertama sampai dengan pertemuan keempat pada pembelajaran di kelas X IIS 2, dan (2) persentase keterlaksanaan pembelajaran pada pertemuan pertama sampai dengan pertemuan ketiga pada pembelajaran di kelas XI MIA 4.

Beberapa kondisi yang mengakibatkan ketidakterlaksanaanbeberapa kegiatan guru dan siswa dalam pembelajaran di antaranya belum terbiasanya siswa dalam mengajukan pertanyaan tentang materi yang dipelajari dan pelaksanaan pada tahap organisasi melebihi alokasi waktu yang tersedia. Selain itu, terdapat kondisi subjektif di mana guru lupa untuk melakukan suatu langkah pembelajaran. Akan tetapi secara umum, proses pembelajaran berjalan dengan lancar dan menunjukkan suatu kondisi di mana siswa aktif dalam melaksanakan langkah-langkah pembelajaran. Kegiatan diskusi dalam pembelajaran ini dapat berjalan dengan lancar tanpa ada suatu kendala yang berarti. Siswa terlihat aktif selama kegiatan diskusi berlangsung. Aktivitas yang perlu dikelola lebih lanjut adalah aktivitas siswa dalam mengomunikasikan hasil diskusi dan aktivitassiswa dalam menyelesaikan masalah pada tahap Ekstensi. Guru perlu membiasakan siswa untuk mengomunikasikan pemikiran atau hasil diskusi agar siswa tidak canggung dalam melakukanaktivitas tersebut. Di samping itu, guru juga perlu memberikan tugas-tugas bagi siswa dalam menyelesaikan soal-soal berbasis masalah agar siswa lebih terampil dalam melakukan aktivitas tersebut, mengingat alokasi waktu yang tersedia pada setiap pertemuan pembelajaran di sekolah sangat terbatas.

Selanjutnya, analisis tentang keefektifan produk ditinjau dari rata-rata skor efikasi diri siswa dalam belajar geometri dan persentase banyaknya siswa dengan efikasi diri yang minimal termasuk pada kategori "tinggi". Skor efikasi diri siswa tersebut diperoleh dari hasil pengisian angket efikasi diri siswa (AEDS) dalam belajar geometri pada siswa kelas X IIS 2 dan XI MIA 4. Rata-raya skor efikasi diri siswa kelas X IIS 2 dan XI MIA 4 sesudah mengalami pembelajaran secara berturut-turut sebesar 111,32 dan 110,24. Berdasarkan data tersebut, efikasi diri siswa kelas X IIS 2 dan XI MIA 4 termasuk dalam kategori "tinggi". Sementara itu, persentase banyak siswa kelas X IIS 2 dan XI MIA 4 yang memiliki efikasi diri dengan kategori minimal"tinggi" dalam belajar geometri dirujuk pada Tabel 7.

Berdasarkan Tabel 7, persentase banyaknya siswa yang memiliki efikasi diri minimal pada kategori "tinggi" sebesar 84,86\% yang tediri dari 84,00\% siswa kelas X IIS 2 dan 85,71\% siswa XI MIA 4. Berdasarkan uraian tersebut, produk memenuhi kriteria efektif untuk meningkatkan efikasi diri siswa di mana rata-rata skor efikasi diri siswa belajar geometri pada siswa kelas X IIS 2 dan XI MIA 4 
tergolong "tinggi" dan persentase banyaknya siswa dari masing-masing kelas yang memiliki efikasi diri dengan kategori minimal "tinggi" lebih besar dari 80\%.

Tabel 7. Distribusi Efikasi Diri pada Siswa Kelas X IIS 2 dan XI MIA 4

\begin{tabular}{lccc}
\hline & Kategori & X IIS 2 & XI MIA 4 \\
\hline Sangat Tinggi & $12,00 \%$ & $9,52 \%$ \\
Tinggi & $72,00 \%$ & $76,20 \%$ \\
Sedang & $12,00 \%$ & $14,28 \%$ \\
Rendah & $4,00 \%$ & $0,00 \%$ \\
Sangat Rendah & $0,00 \%$ & $0,00 \%$ \\
\hline
\end{tabular}

Tercapainya peningkatan efikasi diri siswa sebagaimana diuraikan pada hasil penelitian ini bersesuaian dengan hasil penelitian Nurfayziah (2012) dan Deswita (2015). Sementara itu, tercapainya kriteria kualitas baik pada produk bersesuaian dengan hasil penelitian Khoiriyah, Suharto, dan Trapsilasiwi (2014). Produk ini dapat digunakan secara efektif untuk meningkatkan efikasi diri siswa dalam belajar geometri.

Adapun secara teori, produk ini memiliki karakteristik atau keunggulan dalam meningkatkan efikasi diri siswa yang meliputi beberapa hal. Pertama, terdapatnya langkah-langkah pembelajaran yang diadaptasi dari model CORE dengan pendekatan saintifik, yaitu tahap Connecting dengan aktivitas mengamati (observing) dan menanya (questioning), tahap Organizing dengan aktivitas mengasosiasikan informasi/eksperimen (experimenting), tahap Reflecting dengan aktivitas menalar (associating) dan mengomunikasikan (communicating), dan tahap Extending dengan aktivitas menyelesaikan masalah geometri. Langkah-langkah tersebut dapat meningkatkan efikasi diri siswa sebagaimana teori yang diungkapkan oleh (Bandura, 1997, pp. 3-5; Brown et al., 2013, pp. 16-19; Margolis \& Mccabe, 2006; Usher \& Pajares, 2009). Kedua, terdapat tujuan dan kegiatan pembelajaran geometri yang diarahkan pada peningkatan efikasi diri siswa. Hal ini menunjukkan adanya konsistensi antara proses dan tujuan pembelajaran. Konsistensi tersebut berpengaruh positif pada kepraktisan produk (Nieveen, 1999, p. 127). Ketiga, terdapat kegiatan pembelajaran yang dirancang untuk memfasilitasi siswa dalam mengonstruksi pengetahuan secara aktif dan memaksimalkan peran guru sebagai fasilitator. Hal ini sesuai dengan teori konstruktivisme yang mana pengalaman belajar merupakan faktor penting bagi siswa untuk mengonstruksi suatu pengetahuan. Sementara itu, pengalaman belajar merupakan faktor yang paling berpengaruh terhadap efikasi diri (Bandura, 1997, pp. 3-5; Brown et al., 2013, pp. 16-19; Usher \& Pajares, 2009); Keempat, terdapat soal-soal berbasis masalah yang sesuai dengan indikator pencapaian KD geometri. Hoffman (2010, p. 277) menyatakan bahwa seseorang dengan efikasi diri yang tinggi lebih banyak dalam berusaha, mencoba masalah-masalah yang lebih menantang secara kognitif, gigih, dan menggunakan strategi-strategi menyelesaikan masalah secara produktif.

\section{SIMPULAN}

Produk penelitian ini adalah perangkat pembelajaran yang dikembangkan dengan mengadaptasi model CORE untuk meningkatkan efikasi diri siswa. Produk tersebut memiliki karakteristik sebagai berikut: (1) memuat langkah-langkah pembelajaran yang diadaptasi dari model CORE dengan pendekatan saintifik, yaitu tahap connecting dengan aktivitas mengamati (observing) dan menanya (questioning), tahap organizing dengan aktivitas mengasosiasikan informasi/eksperimen (experimenting), tahap reflecting dengan aktivitas menalar (associating) dan mengomunikasikan (communicating), dan tahap Extending dengan aktivitas menyelesaikan masalah geometri, (2) memuat tujuan dan kegiatan pembelajaran geometri yang diarahkan pada peningkatan efikasi diri siswa, (3) memuat kegiatan pembelajaran yang dirancang untuk memfasilitasi siswa dalam mengonstruksi pengetahuan secara aktif dan memaksimalkan peran guru sebagai fasilitator, dan (4) memuat soal-soal berbasis masalah yang sesuai dengan indikator pencapaian KD.

Produk memenuhi kriteria valid didasarkan pada hasil validasi ahli. RPP terbukti valid dengan rata-rata skor kevalidan sebesar 164,5 yang termasuk dalam kategori "sangat baik" dan LKS terbukti valid dengan rata-rata skor kevalidan sebesar 76 yang termasuk pada kategori "baik". Produk memenuhi kriteria praktis berdasarkan: (1) keterlaksanaan pembelajaran, produktergolong praktis dengan persentase keterlaksanaan mencapai 95,2\%, (2) penilaian guru, RPP dan LKS tergolong praktis dengan skor kepraktisan secara berturut-turut sebesar 47 dan 26 yang mana keduanya termasuk dalam kategori "sangat baik", (3) penilaian siswa, LKS dan proses pembelajaran termasuk praktis. Rata-rata skor 
kepraktisan berdasarkan penilaian siswa kelas X IIS 2 dan XI MIA 4 secara berturut-turut sebesar 30 dan 31,33 yang mana keduanya termasuk dalam kategori "baik". Proses pembelajarandengan menggunakan perangkat tersebut berdasarkan penilaian siswa kelas X IIS 2 dan XI MIA 4 tergolong praktis dengan rata-rata skor kepraktisan secara berturut-turut sebesar 21 dengan kategori "sangat baik" dan 20 dengan kategori "baik". Produk memenuhi kriteria efektif didasarkan pada hasil angket efikasi diri siswa "sesudah" mengalami pembelajaran, yakni dengan rata-rata skor efikasi diri siswa kelas X IIS 2 dan XI MIA 4 secara berturut-turut sebesar 111,32 dan 110,24 yang mana keduanya termasuk dalam kategori "tinggi". Persentase banyaknya siswa yang memiliki efikasi diri minimal pada kategori "tinggi" sebesar $84,86 \%$ yang tediri dari $84,00 \%$ siswa kelas X IIS 2 dan $85,71 \%$ siswa XI MIA 4.

Produk yang dihasilkan dalam penelitian ini memenuhi kriteria valid, praktis, dan efektif. Oleh karena itu, disarankan kepada guru matematika untuk menggunakan dan/atau mengembangkan produk ini sebagai salah satu upaya meningkatkan kualitas pembelajaran geometri. Produk ini tersedia dalam bentuk soft copy dengan format pdf yang dapat diunduh oleh guru di situs www.dropbox.com, www.4shared.com, www.slideshare.net dan www.academia.edu.

Di samping itu, disarankan guru dmemanajemen waktu dengan sebaik mungkin saat mengaplikasikan model pembelajaranan yang ada pada produk iniagar setiap tahapan pembelajaran dapat terlaksana sesuai yang direncanakan. Pengerjaan latihan soal pada setiap tahap pembelajaran dapat disesuaikan dengan kemampuan siswa dan alokasi waktu yang tersedia. Guru juga perlu membimbing siswa untuk menyelesaikan setiap tahapan pada LKS agar siswa mengalami proses pembelajaran yang lebih komprehensif.

\section{DAFTAR PUSTAKA}

Ayda, E., \& Widjajanti, D. B. (2014). Pengembangan perangkat pembelajaran teorema Pythagoras dengan media berbantuan komputer. Jurnal Riset Pendidikan Matematika, 1(2), 216. https://doi.org/10.21831/jrpm.v1i2.2677

Azwar, S. (2004). Metode penelitian. Yogyakarta: Pustaka Pelajar.

Bandura, A. (1995). Self-efficacy in changing societies. Cambridge, MA: Cambridge University Press.

Bandura, A. (1997). Self-efficacy: The exercise of control. New York, N. Y.: Macmillan.

Bandura, A. (2006). Guide for constructing self-efficacy scales. In Self-efficacy Beliefs of Adolescents (pp. 307-337). Greenwich, CT: Information Age Publishing. https://doi.org/10.1017/CBO9781107415324.004

Borg, W. R., \& Gall, M. D. (1983). Educational research: An introduction. New York: Longman.

Brown, L. J., Malou, J. M., \& Schutte, N. S. (2013). Self-efficacy theory (pp. 13-38). Retrieved from http://samples.jbpub.com/9781449689742/Chapter2.pdf

Bruning, R. H., Schraw, G. J., \& Ronning, R. R. (2010). Cognitive psychology and instruction (5th ed.). Boston, MA.: Pearson Education Inc.

Caine, R. N., \& Caine, G. (1997). Education on the edge of possibility. Alexandria, VA: Association for Supervision and Curriculum Development.

Curwen, M. S., Miller, R. G., White-smith, K. a., \& Calfee, R. C. (2010). Increasing teachers' metacognition develops students' higher learning during content area literacy instruction: Findings from the read-write cycle project. Issues in Teacher Education, 19(2), 127-151.

Deswita, R. (2015). Penerapan model pembelajaran connecting-organizing-reflecting-extending (CORE) dengan pendekatan scientific untuk meningkatkan kemampuan komunikasi dan koneksi matematis serta self-efficacy siswa SMP: Studi kuasi eksperimen pada salah satu SMP negeri di $P$. Universitas Pendidikan Indonesia. Retrieved from http://repository.upi.edu/18026/

Dymock, S. (2005). Teaching expository text structure awareness. The Reading Teacher, 59(2), 177181. https://doi.org/10.1598/rt.59.2.7

Gillies, R. M. (2007). Cooperative learning: Integrating theory and practice. California: SAGE Publications.

Günter, M. A., Estes, T. H., \& Schwab, J. H. (1990). Instruction: A models approach. Allyn \& Bacon.

Henson, K. T., \& Eller, B. F. (2012). Educational psychology for effective teaching. Kendall Hunt. 
Hoffman, B. (2010). "I think I can, but I'm afraid to try": The role of self-efficacy beliefs and mathematics anxiety in mathematics problem-solving efficiency. Learning and Individual Differences, 20(3), 276-283. https://doi.org/https://doi.org/10.1016/j.lindif.2010.02.001

Hosnan, M., \& Sikumbang, R. (2014). Pendekatan saintifik dan kontekstual dalam pembelajaran abad 21: Kunci sukses implementasi kurikulum 2013. Bogor: Ghalia Indonesia.

Khoiriyah, J., Suharto, S., \& Trapsilasiwi, D. (2014). Pengembangan rencana pelaksanaan pembelajaran dan lembar kerja siswa model pembelajaran CORE dengan teknik mind mapping pokok bahasan bangun ruang sisi lengkung kelas IX SMP. KadikmA, 5(3), 137-146. Retrieved from http://jurnal.unej.ac.id/index.php/kadikma/article/view/1382

Margolis, H., \& Mccabe, P. P. (2006). Improving self-efficacy and motivation: What to do, what to say. Intervention in School and Clinic, 41(4), 218-227. https://doi.org/10.1177/10534512060410040401

Menteri Pendidikan dan Kebudayaan Republik Indonesia. Peraturan Menteri Pendidikan dan Kebudayaan Republik Indonesia nomor 64 Tahun 2013 tentang standar isi pendidikan dasar dan menengah, Pub. L. No. 64 (2013). Indonesia.

Menteri Pendidikan dan Kebudayaan Republik Indonesia. Peraturan Menteri Pendidikan dan Kebudayaan Republik Indonesia Nomor 69 Tahun 2013 tentang kerangka dasar dan struktur kurikulum sekolah/madrasah aliyah menengah atas (2013). Indonesia.

Menteri Pendidikan dan Kebudayaan Republik Indonesia. Peraturan Menteri Pendidikan dan Kebudayaan nomor 103, tahun 2014, tentang pembelajaran pada pendidikan dasar dan pendidikan menengah, Pub. L. No. 103, Peraturan Menteri Pendidikan dan Kebudayaan Republik Indonesia (2014).

Menteri Pendidikan dan Kebudayaan Republik Indonesia. Peraturan Menteri Pendidikan dan Kebudayaan Republik Indonesia nomor 59 tahun 2014 tentang Kurikulum 2013 SMA/MA (2014).

Miller, M. D., Linn, R. L., Gronlund, N. E., \& Linn, R. L. (2008). Measurement and assessment in teaching (10 Edition). Boston, MA.: Pearson.

Miller, R. G., \& Calfee, R. C. (2004). Making thinking visible: A method to encourage science writing in upper elementary grades. Science and Children, 42(November/December), 20-25.

Morrison, G. R., Ross, S. M., Kemp, J. E., \& Kalman, H. (2010). Designing effective instruction. New York, N.Y.: John Wiley \& Sons.

National Council of Teacher Mathematics. (2000). Prinsiples and standards for school mathematics. Reston, VA: NCTM.

Nieveen, N. (1999). Prototyping to reach product quality. In Design Approaches and Tools in Education and Training (pp. 125-135). Dordrecht: Springer Netherlands. https://doi.org/10.1007/978-94011-4255-7_10

Novak, J. D., \& Cañas, A. J. (2008). The theory underlying concept maps and how to construct and use them, Technical report IHMC CmapTools 2006-01 Rev 01-2008. IHMC CmapTools. https://doi.org/Technical Report IHMC CmapTools 2006-01 Rev 2008-01

Nurfayziah, P. (2012). Peningkatan kemampuan koneksi matematis dan self-efficacy siswa SMP melalui pembelajaran matematika model CORE. Universitas Pendidikan Indonesia. Retrieved from http://repository.upi.edu/9479/

Rodgers, C. (2002). Defining reflection: Another look at John Dewey and reflective thinking. Teachers College Record, 104(4), 842-866. https://doi.org/10.1111/1467-9620.00181

Santrock, J. (2010). Educational psychology. Handbook of Educational Psychology. https://doi.org/10.1146/annurev.ps.05.020154.002041

Schunk, D. H. (1995). Self-efficacy, motivation, and performance. Journal of Applied Sport Psychology, 7(2), 112-137. https://doi.org/10.1080/10413209508406961

Soekamto, T., \& Winataputra, U. S. (1997). Teori belajar dan model-model pembelajaran. Jakarta: PAU-PPAI, Universitas Terbuka. 
Suyatno, D. (2009). Menjelajah pembelajaran inovatif. Sidoarjo: Masmedia Buana Pustaka.

Trianto, T. (2010). Model pembelajaran terpadu: Konsep, strategi, dan implementasinya dalam Kurikulum Tingkat Satuan Pendidikan (KTSP). Jakarta: Bumi Aksara. https://doi.org/2010

Usher, E. L., \& Pajares, F. (2009). Sources of self-efficacy in mathematics: A validation study. Contemporary Educational Psychology, 89-101. https://doi.org/10.1016/j.cedpsych.2008.09.002

Wade, C., \& Tavris, C. (2007). Psikologi. (T. P. Mursalin \& Dinastuti, Ed.). Upper Saddle River, NJ: Pearson Education.

Zimmerman, B. J. (2000). Self-efficacy: An essential motive to learn. Contemporary Educational Psychology, 25(1), 82-91. https://doi.org/10.1006/ceps.1999.1016 